\title{
Assessing local-level forest use and management capacity as a climate- change adaptation strategy in Vhembe District of South Africa
}

\author{
Chidiebere Ofoegbu $^{1,2, *}$, P.W. Chirwa ${ }^{1}$, J. Francis ${ }^{3}$ and F.D. Babalola ${ }^{1,4}$ \\ ${ }^{1}$ Forest Science Postgraduate Programme, University of Pretoria, 5-15 Plant Sciences Complex, Pretoria, South \\ Africa \\ ${ }^{2}$ African Climate and Diversity Initiative, University of Cape Town, Rondebosch 7700, South Africa \\ ${ }^{3}$ Institutes for Rural Development, University of Venda, Thohoyandou 0950, South Africa \\ ${ }^{4}$ Department of Forest Resources Management, University of Ilorin, Ilorin, Nigeria \\ *Correspondence: ofoegbu.c@gmail.com
}

\section{ABSTRACT}

Community-based forest management is a key climate change adaptation initiative in South Africa. It is aimed at enhancing sustainability of rural household livelihoods and livelihood resilience against climate variability and change. However, lack of capacity at local household level could negate the intended benefits of community-based participatory forest management initiatives. This paper examines the local-level forest use and management capacity of rural households in Vhembe district of South Africa with respect to their adaptation strategy to climate change using the concept of livelihood resilience. A stratified proportionate random sampling technique was used to select 366 households from the study area, which were then sampled through household questionnaire survey. The results showed that households' capacity to participate in, and community leadership ability to mobilize people for participatory forest management was low. Nevertheless the results revealed a widespread aspiration in the study communities to take part in forest management and development initiatives. This calls for the need for significant technical support for households and community leaders towards promoting participatory forest management as a way of ensuring efficiency and effectiveness of forest-based adaptation interventions. 
Keywords: participatory forest management, rural community, forest resources, climate change, capacity, coping strategy

\section{INTRODUCTION}

Forests provide important social, economic and ecological functions, and are essential components of climate-change mitigation and adaptation strategies at local, national, and regional level (Dlamini, 2014; Williams et al., 2005). Over 60\% of Africa's population depends on forests for food, firewood, charcoal, medicines, building materials, fodder, etc. (Muoghalu, 2012; Wiersum, 1997). Globally, emissions from the forest sector account for $28 \%$ of global greenhouse gas emissions (Fearnside, 2000). Not surprisingly, discourses around forest use and management have continued to occupy the spotlight in debate and actions about climate change management (Leipold, 2014; Naidoo et al., 2013; Tompkins and Adger, 2004). In most developing countries, forest-based adaptation initiatives, for example community-based forest management, are increasingly acknowledged to have advantages over other adaptation initiatives (Ribot, 2003; Smith \& Scherr, 2002).

Forest-based adaptation initiatives have strong linkages with sustainable rural development (Patosaari, 2007), and enhancement of rural lives and livelihood resilience against climate variability and change (Dlamini, 2014; Bowler et al., 2010). From the livelihood perspective, forests provide many direct and indirect benefits to rural households (Shackleton, Campbell, Wollenberg, \& Edmunds, 2002). Commonly cited direct benefits include (i) provisioning of households with goods either for meeting basic needs or for cash saving particularly during periods of hardship, and (ii) Small-scale trade in forest goods (Shackleton, Shackleton, Buiten, \& Bird, 2007). Most indirect benefits of the forest to rural households include (i) provisioning of browse and fodder for livestock, and (ii) tourism enterprises (Shackleton et al., 2007). The rural people normally turn to forest resources in coping with climate and socioeconomic challenges. Thus, forests are an important component of the adaptation strategies needed to address the direct and indirect effects of climate change on rural people and their livelihoods (Locatelli et al., 2010; Naidoo et al., 2013; Nkem et al, 2007).

In South Africa's rural communities, the dominant livelihood strategies are based on forestry and agriculture (Isaacs \& Mohamed, 2000). Forest products such as firewood, wild berries, and Mopane worms are a significant component of these rural households' livelihood 
strategies for coping with climate variability and extreme weather events (Paumgarten \& Shackleton, 2011; Vedeld et al., 2004). In addition, the South African National Climate Change Response Strategy recognized the forest sector as being central to rural household livelihood sustenance and resilience against climate variability and change (Ziervogel et al., 2014; DEA, 2011). However, poor management and exploitation of forests resources, coupled with weak capacity in forest management have become major challenges, characterizing forest use and management in most rural communities (Department of Agriculture Forestry and Fisheries (DAFF), 2010; Holmes-Watts \& Watts, 2008). Inclusion of rural people in forest management has consequently become an important legislative and political target for attaining sustainable forest management, and resilient rural development (Turpie \& Visser, 2013; DAFF, 2010; Von Maltitz et al., 2003).

As a result, community-based forest management has become the focus of climate change adaptation initiatives in several rural communities (Linkd 2013; Quinn et al. 2011). The South African government's approach to community participation in forest management is premised on the principle of shared benefits, responsibilities, control, and decision making over forest use and management between state and local communities (Chirwa et al., 2015; Holmes-Watts \& Watts, 2008). However, the implementation of participatory forest management initiatives has often failed to strengthen local livelihood strategies and foster sustainable forest use (Holmes, 2007; Isaacs \& Mohamed, 2000). There is thus growing concern over ways in which to implement sustainable community-based forest management that would maximally deliver sustained benefits, employment, income, forest goods and services to local participants as a way of ensuring their livelihood sustenance and resilience against climate variability and change (Arrikum, 2014; Linkd, 2013).

In spite of the efforts to understand the failure of participatory forest management (HolmesWatts \& Watts, 2008; Fabricius, 2004), there are considerable gaps. Questions about rural communities' capacity to meaningfully participate in forest management remain largely unanswered. Holmes-Watts and Watts (2008) observed that several participatory forest management projects have focused on benefit sharing through employment, while ignoring the sharing of management responsibilities and decision making (Holmes-Watts \& Watts, 2008). Additionally, lack of experience and innovation on the part of officials operating in grassroots communities was identified as a limiting factor to the implementation of effective people-centred community forest management (Fabricius, 2004; Holmes, 2007). 
Furthermore, Holmes (2007) and Isaacs and Mohamed (2000) observed that there was limited state capacity to implement participatory forest management policies effectively. Fabricius (2004) and Holmes-Watts and Watts (2008) noted that capacity-building initiatives aimed at promoting effectiveness and efficiency of participatory forest management initiatives concentrated solely on state forest department personnel. Capacity enhancement of rural people for meaningful participation in forest management has consequently been grossly neglected (Underwood, 1999).

This study attempted to fill this gap. The study objective examined households' dependence on forests, forest management capacity and community organization to foster sustainable forest management. The study provided insight into ways to enhance sustainable utilization of forest resources and improve forest management capacity at rural community level in South Africa. This, in turn, will ensure sustained forest-based livelihoods and household livelihood resilience against climate change. This is especially pertinent to understanding how effectively and efficiently forest-based climate-change adaptation initiatives could be implemented. The following research questions were used as a guide for the study objective:

i. How do forests contribute to households' livelihood strategies vis-à-vis sustenance and income?

ii. How do the people perceive the importance of forests to their livelihood resilience against climate variability and change?

iii. Do the people have the aspirations, opportunities and community organizations to engage in participatory forest management?

iv. What technical capacity, education and skills are available in households to enable them to participate meaningfully in sustainable forest management?

The term 'natural forest' as adopted in this study follows the definition used in the South Africa National Forestry Act of 1998 and includes tree plantations, thickets and woodlands (Von Maltitz et al., 2003). The study used the concept of climate change in a broad context and it includes changes in variability and extreme weather events. Furthermore, participation was perceived in line with the definition of Kalim et al. (2013), and Isager et al. (2002), that is, actual involvement of local people in the planning, organization and decision-making processes of forest management. 


\subsection{METHODOLOGY}

\subsection{Framing Livelihood Resilience with respect to Forest Management}

The concept of resilience has emerged as a criterion for managers and decision makers as they attempt to ensure the sustained functioning of the complex and interconnected forest ecosystems in the face of climate change and socioeconomic challenges (Connelly, 2017). Folke (2006) defined resilience to climate change as, "the capacity of a socioecological system to (1) absorb stresses and maintain function in the face of external stresses imposed upon it by climate change and (2) adapt, reorganize, and evolve into more desirable configurations that improve the sustainability of the system, leaving it better prepared for future climate change impacts".This definition identified two key resilience features synonymous with socioecological systems: (1) the system ability to absorb, changes in condition to a certain extent and, (2) the system ability to adapt to different shocks and stresses (Conelly 2017; Folke 2006).

As noted by Tschakert and Dietrich (2010), a livelihood perspective helps to strengthen resilience thinking by placing greater emphasis on human needs, empowerment, and rights in the context of wider transformational changes. Hence, the study concept of livelihood resilience is adapted from Folke's (2016) definition of resilience and Tschakert's and Dietrich's (2010) postulation. The study framing of livelihood resilience is focused solely on forest based livelihood with specific attention on the "adapt" feature of resilience. Thus the term livelihood resilience as used in this study implies both the ability to adjust and/or adapt to the observed and projected impact of climate change on forest based livelihood (Tompkins and Adger, 2004). Accordingly, we define livelihood resilience with respect to forest management at rural community level as the capacity of all people within a community to sustain and improve their forest based livelihood opportunities and well-being despite environmental, economic, and social and political disturbances. Such resilience in the context of South Africa's forest based rural communities will be underpinned by government agencies, individuals and community capacity to act collectively towards sustainable exploitation and management of forest resources (Tanner et al., 2015; Speranza et al., 2014; Naidoo et al., 2013). 
As suggested by Linkov et al. (2014), strategies to build resilience can take the form of flexible response, distributed decision making, modularity, redundancy, ensuring the independence of component interactions or a combination of adaptive strategies to minimize the loss of functionality and to increase the slope of the recovery. Thus we pay special attention on rural people's level and forms of dependence on forests for livelihood, and modalities for enhancing the people's capacity to engage in sustainable forest use and management. Accordingly, the study examines the capacity of local people to engage in sustainable forest management as a means of aiding the capacity of the forest ecosystem to withstand climate stress while sustainably providing the dependent communities with the much needed goods and services for livelihood.

The South Africa's National Forests Act, 1998 (Act 84 of 1998), and the Forestry Law Amendment Act, 2005 (Act 35 of 2005), stipulate the rules and guidelines for fostering sustainable forest management (SFM) in the country (Holmes-Watts and Watts 2008). These policies provide guidelines on how people and communities can use forests sustainably. The South African forest policy and legislation contained 24 sets of principles and criteria, and a series of indicators that are used to conceptualise, evaluate and implement SFM in the country (DAFF 2016). Thus in this study, sustainable forest management was operationalised as households' conformity with government policy and regulation guiding forest management practices at rural community level in South Africa. The study used 12 of the national forest management principles and criteria that apply to communally managed forests in the country to conceptualise SFM (Table 1). These principles were used to design the study questionnaire which investigated the people's level and form of dependence on forest for livelihood as well as their compliance with rules regulating forest exploitation in their locality. 
TABLE I: Criteria and Indicators for fostering sustainable forest management in South Africa

\begin{tabular}{|l|l|}
\hline SN & Criteria \\
\hline 1 & Biodiversity of natural forests is conserved \\
\hline 2 & Forest ecosystem structures are conserved and processes maintained \\
\hline 3 & Forests are protected from negative effects of fire, pests, diseases and alien plants. \\
\hline 4 & Production potential is maintained or improved \\
\hline 5 & Forests make a positive contribution to the economy \\
\hline 6 & The forest economy is resilient \\
\hline 7 & $\begin{array}{l}\text { Cultural, ecological, recreational, historical, aesthetic and spiritual sites and services supplied by } \\
\text { forests are maintained. }\end{array}$ \\
\hline 8 & The distribution of employment benefits from forests is fair \\
\hline 9 & The distribution of the costs from forestry is fair \\
\hline 10 & There is effective stakeholder participation in forestry management \\
\hline 11 & $\begin{array}{l}\text { Forests are developed and managed so that persons or categories of persons previously disadvantaged } \\
\text { by unfair discrimination are advanced. }\end{array}$ \\
\hline 12 & People participate in forestry policy development and review \\
\hline
\end{tabular}

\subsection{Description of study areas}

This study was carried out in the forest-based rural communities of Mutale, Makhado and Thulamela local municipalities in Vhembe District, Limpopo, South Africa (Figure I). The District settlement pattern is largely rural, reaching $90 \%$ of the total population. Vhembe district has the second lowest access to infrastructure amongst Districts in the province. The climate of the study area varies spatially from being arid to semi-arid in Mutale area to temperate and sub-tropic in Makhado and Thulamela areas, respectively (Rosmarin 2013). According to the South African National Climate Change Response Strategy projection for Vhembe, a temperature increase in the range of $1{ }^{\circ} \mathrm{C}$ and $3{ }^{\circ} \mathrm{C}$ by the mid twenty-first century is expected (DEAT, 2004). A broad reduction of rainfall in the range of 5\% to $10 \%$ is also predicted for the region (DEAT, 2004). This is expected to pose severe consequences for dominant rural livelihood strategies, such as farming, livestock-keeping and forest-product use, thereby increasing the vulnerability of rural communities in the area (Turpie \& Visser, 2013; Paumgarten \& Shackleton, 2011). The region therefore represents a representative case for an evaluation of the roles that forests plays in rural livelihood strategies and adaptation to climate-change adaptation. 


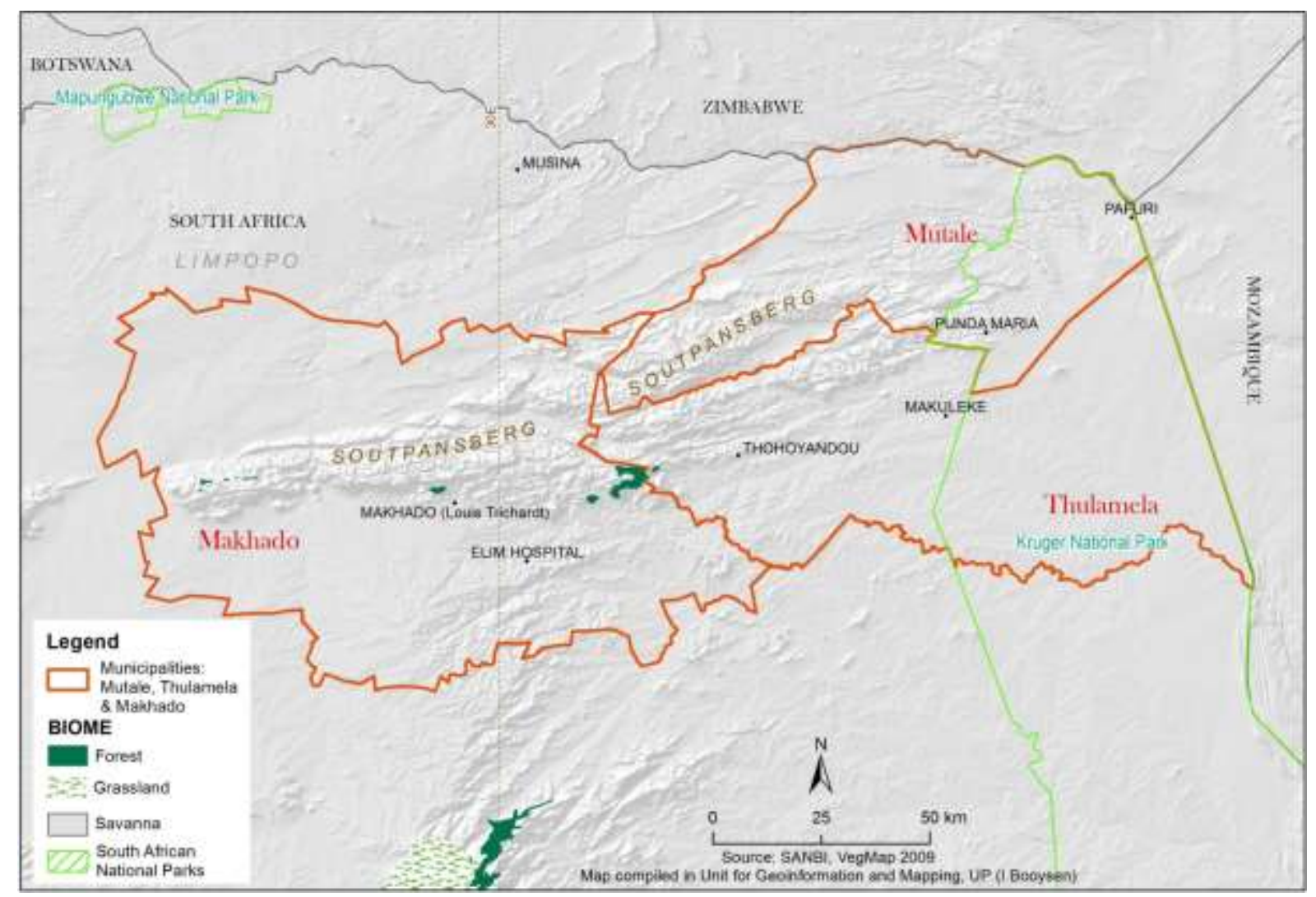

FIGURE I: Biomes of Vhembe District in South Africa

\subsection{Questionnaire survey and Sampling procedure}

In each of the selected municipality, we further selected a replicate of seven rural communities, which gave a combined total of 21 rural communities. A grand total of 366 households were then selected from these communities using stratified proportionate random sampling procedure. The field survey was from August 2013 to September 2014. For questionnaire administration, each selected household was subjected to a non-probability purposive sampling technique whereby we selected a respondent from the household that (a) were over 20 years of age and (b) had lived more than five years in the community.

The study questionnaire contained both open and closed-ended questions, which had been translated into the local language (Tshivenda) in use in the study area. The questionnaire was pre-tested and adjusted to suit the situation in the field. Questions were based on 12 of the national forest management principles and criteria that apply to communally managed forests in South Africa (Table 1). They were designed to tap into respondents' knowledge and experience of forest regulations and management in the community; households' dependence on forest products for livelihoods; the role of forest products in household adaptation to 
climate variability; households' capacity to participate meaningfully in forest management; and community leadership capacity to influence participation in forest management. A 4point Likert scale ( 1 = high, 2 = medium, 3 = low, and 4 = no contribution) was used to analyse perceived benefits of forests to household income, sustenance, and livelihood resilience against climate variability and change.

\subsection{Data Analysis}

Data from the questionnaire survey were subjected to weighting adjustment to correct for possible problems of over- and under-representation of variables (Bethlehem 2015). The sample was weighed against the actual population to arrive at weighted sample. The weighted data were then subjected to statistical analysis using the Statistical Package for the Social Sciences (SPSS) (Levesque, 2007).

Discrete variables were summarized by the frequency of each code in the questionnaire, and summary statistics were computed for all numeric variables. Categorical data on the opinions of respondents were analysed based on individual responses. Descriptive statistics and chisquare tests were used to analyse households' dependence on forest resources, the current role of forest products in household coping strategies for climate variability and change; opportunities for participatory involvement in forest management; people's qualifications, skills and capacity to foster sustainable forest management; and factors that influence households' desire to engage in these practices. Chi-square and Bonferroni tests were used to analyse associations between respondents' age and lack of interest in participating in forest management. The Pearson chi-square was used where the expected cell frequency was $\geq 5$, while M-L chi-square was used when the expected cell frequencies were lower than 5 (Turyahabwe et al., 2006). However, to identify variables that were independent predictors of participation in forest management, we used logistic regressions from which the estimated odds ratios (y) were derived to ascertain the effects of the predictors on respondents' participation in forest management. Odds ratios were used to measure the magnitude of strength of association or non-independence between two binary data values. A p-value of $p$ $<0.05$ represented statistical significance in hypothesis testing and 95\% confidence intervals were used to describe the estimation of unknown parameters (Clewer \& Scarisbrick, 2001).

\section{Specification of the logistic regression model}

The target modelled variable was participation in forest management. The researchers took 
each indicator as a binary outcome, and used logistic regression to model a number of explanatory variables, including employment status (yes 1; no $=0$ ), farming skills (yes 1; no $=0$ ), livestock-keeping skills (yes 1 ; no $=0$ ), carpentry skills (yes 1 ; no $=0$ ), years of residency $(\leq 38)$ (yes 1 ; no $=0$ ), years of residency $(39-52)$ (yes 1 ; no $=0$ ), years of residency $(53-65)($ yes 1 ; no $=0)$, years of residency $(66+)$ (yes 1 ; no $=0)$, age of respondent $(\leq 38)$ (yes $=1$; no $=0)$, age of respondent $(39-52)$ (yes =1; no =0), age of respondent $(53-65)$ (yes = 1 ; no $=0$ ), age of respondent $(66+)$ (yes $=1 ;$ no $=0$ ), and academic qualification (yes $=1 ;$ no $=$ 0 ). The chi-square test at $a=0.05$ significance level was used to assess the goodness of fit of the models.

\section{RESULTS}

In this section, we present the results of the survey of households' dependence on the forest sector, and their capacity to participate meaningfully in forest management.

\subsection{Household dependence on forests}

Households' dependence on forests was examined in terms of formal and informal forest sector contribution to household income. We used the work of Arrikum (2014), Ole-Meiludie and Mwihomeke (2006), and results from the reconnaissance survey to identify key formal forest sectors in the areas and examined their contributions to household income. The contribution of the informal sector was examined in terms of provision to household income and subsistence.

Despite the abundance of forests in the area (CoGTA, 2012; Ole-Meiludie and Mwihomeke, 2006), the contribution of formal forest sector to household income was generally low, and varied significantly $(\mathrm{P}=0.000)$ per sectors and municipalities. The five formal forest based sectors surveyed: tourism, sawmill, tree plantations, furniture and wood artisan/carving, were observed to make varying contributions to households income in the municipalities. In Thulamela, tree plantations (60.4\%), sawmills (56\%), and tourism (51\%) were the three top contributing sectors to household income. In Makhado and Mutale, the contributions of the formal forest sector to household income were significantly low. In Mutale, tree plantation (43\%) and Woodwork/carving/artisan (33\%) were the top contributing sectors to household income. While in Makhado, sawmill (19\%) and the furniture industry (16\%) was the top contributing sectors to household income. 
However, income from the informal forest sector in the area was relatively high. Firewood and construction wood/timber were the most commonly traded forest products in the area and the highest contributors to household income. The commonly used tree species for firewood are the Acacia and Eucalyptus. Firewood contribution to household income was observed to be significantly different $(\mathrm{P}=0.000)$ among the municipalities. The majority of respondents in Makhado (97.5\%), Mutale (97.2\%), and Thulamela (68\%) rated the firewood contribution to their household income as high. The Bonferroni test, however, showed that firewood contribution to household income did not differ significantly between Mutale and Makhado, but Thulamela was significantly difference $(P=0.000)$ from the two municipalities. Unlike other parts of Africa, charcoal and mushroom were not popularly traded for income by households in the area. The majority of respondents in Makhado (81.2\%), Mutale (71.4\%), and Thulamela (84\%) were not involved in sale of charcoal. This was mainly because culturally people prefer firewood and rarely use charcoal for cooking. Likewise, most respondents in Mutale (58\%) and Thulamela (57\%) were not involved in the sale of mushrooms.

Households in the area used various types of forest products for subsistence. Common products used by households in the area included firewood, forest fruits and food (e.g. wild berries), timber/construction wood, thatch grass, bush meat/edible insects (e.g. wild pig, mopane worms and termites), weaving fibre, fodder, medicinal plants, honey and mushrooms. These products were generally used for subsistence and as safety nets in times of shocks e.g. crop failure as a result of drought.

Use of forest products as a coping mechanism for direct and indirect impacts of climate variability and extreme weather events in the study area was very high. Trade in non-timber forest products (NTFPs) such as amarula fruits and mopane worms was often used by households as income diversification strategies in coping with extreme weather events such as drought, erratic rainfall and crop failure. This was used to cushion the cost of extreme weather events on households' livelihood e.g. subsistence farming. More than $60 \%$ of respondents in Makhado and Thulamela and 49\% in Mutale rated their use of forest products as coping mechanisms when affected by climate variability and extreme weather events as very high (Table II). The relatively lower percentage recorded at Mutale could be attributed largely to the current conditions of most forests in the region. Mutale is in a semi-arid region where most forests are degraded and have low capacity to provide essential goods and 
services needed by households for their livelihoods. Consequently, they play a lesser role as household coping strategies.

TABLE II: Respondents' level of dependence on forest product when affected by climate hazards

\begin{tabular}{|c|c|c|c|c|}
\hline \multirow[t]{2}{*}{ Forest product } & \multirow[t]{2}{*}{ Contribution rating } & \multicolumn{3}{|c|}{ Proportion of respondents $(\%)$ in } \\
\hline & & $\begin{array}{c}\text { Makhado }(n= \\
156)\end{array}$ & $\begin{array}{c}\text { Mutale (n }= \\
\text { 110) }\end{array}$ & $\begin{array}{c}\text { Thulamela }(\mathrm{n}= \\
100)\end{array}$ \\
\hline \multirow[t]{4}{*}{ Erratic rainfall } & High & 61.0 & 34.8 & 67.0 \\
\hline & Low & 26.6 & 54.5 & 3.0 \\
\hline & No change & 9.1 & 2.7 & 12.0 \\
\hline & No contribution & 3.2 & 8.0 & 18.0 \\
\hline \multirow[t]{4}{*}{ Serious flood } & High & 53.9 & 33.0 & 67.0 \\
\hline & Low & 24.7 & 52.7 & 5.0 \\
\hline & No change & 9.7 & 6.3 & 16.0 \\
\hline & No contribution & 11.7 & 8.0 & 12.0 \\
\hline \multirow[t]{4}{*}{ Drought } & High & 59.7 & 33.9 & 60.0 \\
\hline & Low & 22.7 & 54.5 & 5.0 \\
\hline & No change & 8.4 & 7.1 & 20.0 \\
\hline & No contribution & 9.1 & 4.5 & 15.0 \\
\hline \multirow[t]{4}{*}{ Extreme temperature } & High & 68.8 & 35.7 & 62.0 \\
\hline & Low & 22.7 & 53.6 & 9.0 \\
\hline & No change & 3.9 & 6.3 & 20.0 \\
\hline & No contribution & 4.5 & 4.5 & 9.0 \\
\hline
\end{tabular}

The highest use rate of forest products as a coping mechanism among respondents in Makhado and Mutale occurred when responding to the effects of extreme temperatures. However, for respondents in Thulamela, the highest use of forest products as a coping mechanism occurred when dealing with the effects of erratic rainfall and floods.

\subsection{Forest management capacity and participation in forest management}

One way of improving forest-based adaptation strategies at community level is to strengthen local capacity so that communities are able to adjust, and participate meaningfully in sustainable forest management (Pramova et al., 2012). Thus, we examined people's capacity to significantly take part in forest management.

\subsubsection{Current level of participation in forest management}

The level of participation in forest management was examined by asking the respondents if they were involved in any way in forest management in their community. Although the Bonferroni test showed that the level of participation in forest management in Makhado 
(5.8\%) was significantly different from that in Mutale (16.4\%) and Thulamela (16\%), there was generally a low rate of participation in the study communities. The survey indicated that over $70 \%$ of respondents were not involved in any way in forest management in their community. Additionally, the chi-square test indicated that there was a significant difference $(\mathrm{P}=0.009)$ in the current level of participation in forest management across the municipalities.

Furthermore, we investigated factors that drive participation in forest management as a way of determining a strategy to improve the local residents' involvement in forest management. We used logistic regression to examine socioeconomic variables that promote participation in forest management. The result revealed that participation in forest management in the study communities was significantly $(\mathrm{P}=0.000)$ influenced by possession of farming skills, while employment status, years of residency, age and other skills (carpentry and animal husbandry) were not.

\subsubsection{Capacity to participate in sustainable forest management}

Meaningful participation in forest management requires that households should have adequate capacity to manage forest resources. Turyahabwe et al. (2006) described capacity as possession of the appropriate legal framework, knowledge, skills and abilities to fulfil a given role. We examined the educational level as an enabler of that capacity. Pearson's chi-square test showed a significant association $(\mathrm{P}=0.001)$ between respondents and educational level. Mutale (73.4\%) had the highest rate of respondents without qualifications. This was followed by Makhado (64.6\%), then Thulamela (45.5\%). Furthermore, the Bonferroni test showed that the proportion of respondents without qualifications was not significantly different between Makhado and Mutale.

In addition, we examined skills related to forest management and forest business that respondents had acquired through experiential learning and informal training. In this regard, we assessed respondents' possession of hunting, carpentry, craft work, farming, and livestock keeping skills. Possession of these types of skills was found to be low. Possession of hunting, farming, and livestock-keeping skills was found to differ significantly $(p<0.05)$ while possession of carpentry and wood carving/craft work skills did not differ significantly $(\mathrm{P}>0.05)$ across the municipalities. Possession of farming skills was very high in Makhado (65.4\%), and Mutale (78\%), but low in Thulamela (40.2\%). Similarly, having livestockkeeping skills was high only in Mutale (80.7\%), but below 24\% in Makhado and Thulamela. 
However, possession of other skills, such as carpentry and wood carving, was generally poor $(<5 \%)$ in all the municipalities. Owning these skills could potentially enhance people's participation in forest enterprises for sustenance and livelihood resilience.

In addition, capacity enhancement opportunities in the community via participation in forest management training programmes were examined. Respondents were asked how often they attended training in forest management practices. Training opportunities for capacity improvement in forest management were very poor in all the study communities. This was especially worrisome in Makhado (73.4\%), and Mutale (81.3\%), where the majority of respondents had not attended any form of training in forest management. In addition, the Pearson chi-square test showed a significant difference $(P=0.000)$ in frequency of participation in forest management training across the municipalities.

Furthermore, we assessed the training needs of the people for capacity improvement towards meaningful participation in forest management by asking them to indicate the types of training that would most interest them in order to improve their ability to participate meaningfully in forest management. The majority of respondents expressed the need for indepth training in several types of forest management practices to improve their capacity to participate meaningfully in integrated sustainable forest management. Respondents in Makhado (33.3\%) and Mutale (35.5\%) were more interested in training in sustainable forestresource harvest practices, while respondents in Thulamela $(23.8 \%)$ were more interested in training in best practices in forest regeneration. Provision of these skills would facilitate participation in forest rehabilitation and sustainable forest management programmes. Interestingly, there was also significant interest in training in business skills, NTFPs and forest product marketing.

\subsubsection{Ability of community leadership structure to influence participation in forest management}

Recognizing that community leadership structures are essential in mobilizing the people to participate meaningfully in forest management, we examined the community level of contentment with their leadership structure by probing their satisfaction with opportunities to contribute to local decision making. Apart from Makhado, where 51.3\% of respondents were satisfied or very satisfied, satisfaction was generally low in Thulamela (47\%) and Mutale 
(29.6\%). Satisfaction with community leadership did not differ significantly between Mutale and Thulamela, but did differ significantly between Makhado, and Mutale/Thulamela.

\section{DISCUSSION}

\subsection{Household dependence on forests}

Results from this study indicate a high level of household dependence on the informal forest sector for subsistence and income. This sector had been a significant contributor to rural household income and subsistence in South Africa (Munyanduki, 2014; DWAF, 2005; Shackleton, 2004; Vedeld et al., 2004). In addition, forests currently play a significant role in household livelihood coping strategies to climate shocks. Most respondents are involved in small-scale trading of forest products as a strategy for coping with socioeconomic pressures such as unemployment, and climate variability and change, for example drought and erratic rainfall. This is consistent with the report by DWAF (DWAF, 2005), which recorded widespread informal trade in forest products in rural communities and in urban areas. Indeed, the use of forest products as a coping mechanism for climate change is a common livelihood strategy in several African countries (Pramova et al., 2012; Somorin, 2010).

Forests could therefore form the basis of household livelihood adaptation to climate change in the study communities. However, evidence from this study suggests that the potential role of forests in rural development and household resilience against climate risk has not been fully utilized. This is evident in the current low contribution of the formal forest sector to household income in the study area. With the exception of Thulamela, the formal forest sector contribution to households' income in Mutale and Makhado municipalities is significantly low. This seems to be a common trend in rural communities, particularly those in natural forests or on the periphery, as evidenced in previous studies (Lewis et al., 2003; 2005). Nevertheless, evidence from other regions of South Africa, where the formal forest sector is well developed, shows that the formal forest sector could be a major contributor to rural development and household livelihood sustainability and resilience (Chamberlain et al., 2005). Improving the contribution of the forest sector to household livelihoods and livelihood resilience in the study communities would therefore require development of the formal forest sector.

This would require the adoption of strategies to improve household capacity to participate in forest enterprise and forest management as a way of decoupling current forest-based 
livelihood activities from destructive forest exploitation practices. This will entail investigation of practicable models of livelihood diversification through participatory forest management in plantation forest management and development (Bele et al., 2015). As noted by Ruiz-Mallen et al (2015), involvement of local people in planning for adaptation to socioecological changes is vital for the strengthening of local efforts in dealing with climate change challenges. Thus capacitating local people to participate effectively in forest management and forest enterprise development in the study region is crucial in order to broaden and improve the forest sector contribution to households' livelihood thereby addressing challenge of local livelihood sustainability and resilience to climate change challenges.

The dependence on forests for livelihood can serve as either a barrier or opportunity for improving the people livelihood resilience to climate change. It can serve as an opportunity if the people are provided with technical and financial support to enable them take advantage of the thriving forest sector in their community to enhance their livelihood sustainability and resilience to climate and socioeconomic challenges. Evidence from other studies both in South Africa and elsewhere in developing countries suggest that when people are capacitated they are able to maximally take advantage of opportunities within the forest sector in their locality to build a sustainable and resilient livelihood (Hajost and Zerbock, 2013; UNDP, 2013). For example, the capacitation of rural households to adopt agroforestry practices in Kenya and Tanzania was found to have positive influence on forest protection and erosion control (UNDP, 2013). Likewise, capacitation to participate in forest enterprise e.g. small scale sawmill, craft and carving business, etc. was observed to increase the resilience, sustainability and contribution of forest based livelihood to household income (Shackleton et al., 2002), In addition, the people are able to organise themselves, to engage in sustainable exploitation and management of the forests in their locality. These will have positive impact on the sustainability of forest based livelihood strategies (UNDP, 2013; Shackleton et al., 2002). However, when the people are not capacitated, dependence on forest for livelihood becomes a barrier to livelihood resilience as the people are confined to a cycle of poverty as a result of illegal and unsustainable use of forests for livelihood. This confines the people to an unsustainable livelihood practice which increases their sensitivity to climate change and socioeconomic challenges (Shackleton, 2004). 


\subsection{Forest management capacity and participation in forest management}

A livelihood resilience lens incorporates people's capacity enhancement perspective into resilience thinking (Sen, 2004). This view is also echoed by Sallu et al (2010) where they opined that resilience framing will entail people's ability to cope with the shocks that they are at risk of experiencing. With respect to forest based livelihood, this will entail capacitating the communal forest users to be able to adopt sustainable forest use and management. This will enhance the capacity of the forest ecosystem to be able to absorb disturbance, adapt and maintain equilibrium while sustainably supplying the communal forest users with the needed goods and services for livelihood (Speranza et al., 2014).

Ensuring the sustainability and effectiveness of rural people's participation in forest management requires that they have the capacity to participate meaningfully. Evidence from this study suggests that the people have weak capacity to participate meaningfully in forest management in terms of skills, education, knowledge of forest regulation legislation, and community organization in all the study communities. This challenge is a widespread phenomenon in Vhembe and has been cited as a significant threat to sustainable development in the district (CoGTA, 2012; Mpandeli, 2014). Furthermore, weak capacity at rural community level has serious implications for promoting sustainable forest utilization and management in the study communities. As observed by Nelson and Agrawal (2008), capacity development at rural community level has a positive correlation with the sustainability and effectiveness of community forest and forest-based adaptation initiatives. Similarly, Shackleton et al. (2002) observed that in places where local people were well organized and had associations with non-governmental organizations (NGOs), the effectiveness of community forestry was ensured, and local participants enjoyed greater benefits from the initiative. Furthermore, it has been argued that local people's awareness of their rights and knowledge of forest policy documents and legislation significantly affects the level of benefit they obtain from community forest initiatives (Shackleton \& Campbell, 2001).

Despite their inadequate capacity to participate in forest management, there is widespread aspiration in the study communities to take part in forest management and development initiatives. Respondents expressed interest in training in various aspects of forest management as a way of enhancing their capacity to participate sustainably. Providing the people with the requisite skills is therefore necessary for effective forest-based adaptation 
initiatives in the communities (Holmes-Watts \& Watts, 2008; Perlis, 2009; Ribot,, 2003; Turyahabwe et al. 2006). Rural household capacity enhancement is an important tool for promoting green entrepreneurship and decoupling household livelihood activities from destructive forest-use practices in the rural areas of Vhembe (Musyoki, 2012). However, the challenge lies in the lack of or inadequate opportunities to participate in forest management training in all the study communities. In most cases, respondents indicated that they have never participated in forest training programmes. The onus therefore is on the Department of Forestry personnel to provide these opportunities. They need to expend more effort in operationalizing South African forest policy and green growth strategy provisions for local people to have meaningful engagement in green forest enterprise development and sustainable forest management.

Moreover, the South African Forestry Department does not have sufficient human resources to directly manage all forests in rural communities in South Africa (Berliner, 2005). A more reasonable approach would be for the department to take advantage of local leadership structures in the study communities, in providing the people with required skills and training. This might entail involving local leaders in facilitating the provision of forest training and forest enterprise opportunities. However, this would require the strengthening of the local leadership structure particularly where there is dissatisfaction with local leaders. As noted by Larson (2003), when community leadership lacks the required capacity, their control of forest management often leads to greater levels of deforestation. Moreover, trust in community leadership is crucial for the acceptance of community-led forest management initiatives (Benkenstein et al., 2014; Wongbusarakum \& Loper, 2011). A concerted effort is therefore required by the department to enhance capacity for meaningful participation in forest management to ensure the sustainability of current and potential roles of forests in household livelihoods and livelihood resilience against climate risk. As noted by Linkov et al (2014), enhancing social networks is a component of resilience. This implies that enhancing the capacity of local leadership to foster communal participation in sustainable forest use and management will greatly enhance the sustainability and resilience of forest based livelihood at rural community level in South Africa. 


\section{CONCLUSION AND RECOMMENDATION}

Livelihood resilience is a central concept in this study. The study takes a livelihood-centred perspective on resilience with focus on forest based livelihood. A livelihood resilience framework with respect to forest management and climate change offers a rich plethora of contributions that can improve our understanding of rural livelihood and forest management, and better equip practitioners and policymakers to develop sustainable solutions that combat the effects of climate change on forests and livelihood. If one wishes to help increase the resilience level of forest based livelihoods at rural communities level against socioeconomic and climate change impacts, it is fundamental to understand the peoples' forms of and level of dependence on forests for livelihood, and their capacity to participate in forest management. 
Sustainability of forest contributions to household livelihood and livelihood resilience against climate change, and meaningful participation in forest management are inseparably linked. Findings from this study show that forests and forest products play a significant role in people's livelihoods and livelihood resilience against climate change. However, the people's inadequate capacity and lack of meaningful participation in forest management is limiting the maximization of forest contributions to household livelihood and livelihood resilience. This is also a significant limiting factor in attaining sustainable forest management and forest-based green growth in the study communities. Thus a concerted effort towards providing the people and community leaders with technical assistance to promote the sustainable use of forest resources and enhance their capacity for meaningful participation in forest enterprise business and forest management is recommended as a way of ensuring the sustainability of forests' contributions to people's livelihoods and livelihood resilience against climate risk. Improving the capacity of rural people in South Africa to adopt sustainable forest use and management practices should thus be a prime target for local climate resilience efforts particularly for forest based communities.

\section{Funding}

This work was supported by the South Africa National Research Foundation [grant number UID: 82942].

\section{REFERENCES}

Arrikum JP (2014) Contribution of the South African Forestry Company to sustainable development in the Vhembe District: MSc Thesis, Wits University, Johannesburg, South Africa.

Fearnside P(2000). "Global warming and tropical land-use change: Greenhouse gas emissions from biomass burning, decomposition and soils in forest conversion, shifting cultivation and secondary vegetation". Climatic Change. 46: 115-158.

Berliner D (2005) Systematic conservation planning for the forest biome of South Africa: Approach, methods and results of the selection of priority forests for conservation action. Department of WaterAffairs and Forestry (DWAF).Pretoria, South Africa.

Bethlehem J (2015) Applied Survey Methods: A statistical perspective. Retrieved March 11, 2015, from Weighting adjustment: http://www.applied-survey-methods.com/weight.html 
Benkenstein A, Hengari S, and Mbongo W (2014) Community Forests in Namibia: Ensuring Sustainable Locallevel Forest Management. Pretoria: South African Institute of International Affairs' Policy briefing 119 on Governance of Africa's Resources Programme.

Boon E, and Ahenkan A (2012) Assessing Climate Change Impacts on Ecosystem Services and Livelihoods in Ghana: Case Study of Communities around Sui Forest Reserve. Journal of Ecosystem \& Ecography, S3:1-8. doi:10.4172/2157-7625.S3-001

Bowler D, Buyung-Ali L, Healey JR, Jones JPG, Knight, T and Pullin AS (2010) The evidence base for community forest management as a mechanism for supplying global environmental benefits and improving local welfare. CEE review 08-011 (SR48). Environmental Evidence: www.environmentalevidence.org/SR48.html.

Castro AP, and Nielsen E (2001) Indigenous people and co-management: implications for conflict management, Environmental Science \& Policy, 4(4-5), 229-239.

Chamberlain D, Essop H, Hougaard C, Malherbe S, and Walker R (2005) Part I: The contribution, costs and development opportunities of the Forestry, Timber, Pulp and Paper industries in South Africa. Final report - 29 June 2005. Genesis Analytics (Pty) Ltd. South Africa.

Chirwa, PW, Mamba S, Manda SOM, and Babalola FD (2015) Assessment of settlement models for engagement of communities in forest land under claim in Jessievale and Roburna communities in Mpumalanga, South Africa. Land Use Policy 46: 65-74

Clewer AG, and Scarisbrick DH (2001) Practical statistics and experimental design for plant and crop science. John Wiley \& Sons, Ltd. West Sussex England (ppl-22).

Connelly E.B., Allen C.R., Hatfield K., Palma-Oliveira J.M., Woods D.D., Linkov I. (2017). Features of resilience. Environ Syst Decis (2017) 37:46-50

Cooperative Governance and Traditional Affairs: CoGTA (2012) Vhembe District Municipality Profile. Department of Cooperative Governance and Traditional Affairs.Pretoria, South Africa

Department of Agriculture Fisheries and Forestry: DAFF (2010) Policy Principles and Guidelines for Control of Development Affecting Natural Forests. Department of Agriculture, Forestry and Fisheries (DAFF). Pretoria, South Africa.

Department of Environmental Affairs: DEA (2011) National climate change response white paper. Private Bag X447, Pretoria 0001. https://www.environment.gov.za/sites/default/files/docs/climate_change_governance.pdf

Department of Environmental Affairs and Tourism: DEAT (2004) A national climate change response strategy for South Africa. Department of environmental affairs and tourism. Private Bag X447, Pretoria 0001. https://unfccc.int/files/meetings/seminar/application/pdf/sem_sup3_south_africa.pdf 
Department of Water Affairs and Forestry: DWAF (2005) Draft Key Issue Paper on Forestry and Poverty in South Africa. Department of Water Affairs and Forestry.Pretoria, South Africa

Dlamini CS (2014) African forests, People and Climate change Project: Forest and Climate Changes Policies, Strategies and Programmes in the SADC and COMESA regions. African Forest Forum, Working Paper Series, Vol. 2(17), 39 pp.

Dubois O (1999) Assessing local resilience and getting roles right in collaborative forest management: some current issues and a potential tool, with special reference to sub-Saharan Africa. Food and Agriculture Organization of the United Nations, Pluralism and Sustainable Forestry and Rural Development Food and Agriculture Organization of the United Nations, Rome (1999) (pp. 49-83)

Fabricius C (2004) The fundamentals of community-based natural resource management. In: Fabricius, C., Coch, C., Magome, H., Turner, S. (Eds.), Rights, Resources and Rural Development: community-based natural resource management in southern Africa. Earthscan, London, pp. 3-43

Folke C. (2006). "Resilience: The emergence of a perspective for social-ecological systems analyses". Global Environmental Change. 16: 253-267. doi:10.1016/j.gloenvcha.2006.04.002.

Hajost S, Zerbock O. 2013. Lessons Learned from Community Forestry and Their Relevance for REDD+. Arlington, VA 22209: United States Agency for International Development.

Holmes Tania Natasha (2007) Contribution of the Participatory Forest Management (PFM) intervention to the socio-economic development in the Southern Cape Forests: a retrospective approach. PhD Thesis: University of Stellenbosch, Stellenbosch, South Africa.

Holmes-Watts T, and Watts S (2008) Legal frameworks for and the practice of participatory natural resources management in South Africa. Forest Policy and Economics 10, 435-443.

Isaacs M, and Mohamed N (2000) Co-managing the commons in the 'new' South Africa: room for manoeuvre? Paper presented at the 8th Biennial Conference of the International Association for the Study of Common Property entitled, Constituting the Commons, May 31 - June 4, 2000

Isager L, Theilade I, and Thomson L (2002) People's participation in forest conservation: considerations and case studies. Proceedings of the Southeast Asian Moving Workshop on Conservation, Management and Utilization of Forest Genetic Resources (pp. 1-10). Bangkok: Forestry Research Support Programme for Asia and the Pacific (FORSPA).

Kalim US, Bansha D, Craig J, and Baptiste A (2013) Understanding livelihood vulnerability to climate change: Applying the livelihood vulnerability index in Trinidad and Tobago. Geoforum 47, 125-137.

Larson AM (2003) Decentralisation and forest management in Latin America: Towards a working model.

Public Administration and Development, 23:211-226. 
Leipold S. (2014). Creating forests with words. A review of forest-related discourse studies. Forest Policy and Economics, 40:12-20. doi: 10.1016/j.forpol.2013.12.005

Lewis F, Blanche C, and Todd M (2003) A review of poverty in South Africa in relation to forest based opportunities. Prepared by the INR for DWAF WFSP Forestry Programme (HTS Development Ltd., Making Forestry Work for the Poor project).

Lewis F, Adie H, Howard M, Mitchell F, Stephen B, Ham C, Oelofse C, Brown F, and Mander M (2005) Pilot State of the Forest Report: A pilot report to test the national criteria and indicators, Report prepared by Institute of Natural Resources. Investigational Report Number: 253 for DWAF.

Levesque R (2007) SPSS Programming and Data Management: A Guide for SPSS and SAS Users (4th ed.), Chicago, Illinois: SPSS Inc., ISBN 1-56827-390-8.

Linkd (2013) Climate Change Adaptation Sector Strategy for Rural Human Settlements. Pretoria: Department of Rural and Land Affairs.

Linkov I., Bridges T., Creutzig F., Decker J., Fox-Lent C., Kröger W., Lambert J.H., Levermann A., Montreuil B., Nathwani J., Nyer R., Renn O., Scharte B., Scheffler A., Schreurs M., and Thiel-Clemen T. (2014). Changing the resilience paradigm. Nature climate change | Vol 4 | 407-409

Locatelli B, Brockhaus M, Buck A, Thompson I, Bahamondez C, Murdock T, Geoff R, and Webbe JA (2010) In : Mery Gerardo (ed.), Katila Pia (ed.), Galloway Glenn (ed.), Alfaro René (ed.), Kanninen Markku (ed.), Lobovikov Maxim (ed.), Varjo Jari (ed.). Forests and society : responding to global drivers of change. Vienne : IUFRO, p. 21-42. (IUFRO World Series, 25).

Mendis S, Mills S, and Yantz J (2003) Building community capacity to adapt to climate change in resourcebased communities. Manitoba: Prince Albert Model Forest.

Mpandeli S (2014) Managing Climate Risks Using Seasonal Climate Forecast Information in Vhembe District in Limpopo Province, South Africa. Journal of Sustainable Development, 7(5), 1-18.

Munyanduki P (2014) Community-based socioeconomic sustainability assessment of Gaba and Rossbach government plantations in Limpopo province, South Africa: MSc Thesis, University of Pretoria, Pretoria, South Africa.

Muoghalu JI (2012) Climate vulnerability of biophysical and socio-economic systems and a description of some permanent sample plots in moist tropical forests in West and Central Africa: A platform for stakeholders in African forestry. African Forest Forum, Nairobi

Musyoki A (2012) The Emerging Policy for Green Economy and Social Development in Limpopo, South Africa. Geneva: United Nations Research Institute for Social Development. 
Naidoo S, Davis C, and Van Garderen E A (2013) Forests, rangelands and climate change in southern Africa . Rome: Food and Agriculture Organization of the United Nations (FAO).

Nelson F, and Agrawal A (2008) Patronage or Participation? Community-based Natural Resource Management Reform in Sub-Saharan Africa. Development and Change 39(4), 557-585.

Nkem J, Santoso H, Murdiyarso D, Brockhaus M, and Kanninen M(2007) Using Tropical Forest Ecosystem Goods and Services for Planning Climate Change Adaptation with Implications for Food Security and Poverty Reduction. SAT eJournal, 4(1), 1-23

Ole-Meiludie RE and Mwihomeke ST (2006) Existing Situation of Forest and Wildlife Resources in the Limpopo Province, Department of Forestry, 49876134/SUA, Sokoine University of Agriculture.

Paavola P (2008) Livelihoods, vulnerability and adaptation to climate change in Morogoro, Tanzania. Environmental Science \& Policy, 11( 7), 642-654

Patosaari P (2007) Forests and Climate Change: Mitigation and Adaptation through Sustainable Forest Management. 60th Annual DPI / NGO Conference, "Climate Change: How it Impacts Us All" Roundtable on Coping with Climate Change: Best Land Use Practices (pp. 1-7). New York: United Nations.

Paumgarten F, and Shackleton CM (2011) The role of non-timber forest products in household coping strategies in South Africa: the influence of household wealth and gender. Population and Environment, 33:137,DOI: 10.1007/s11111-011-0137-1

Perlis A (2009) Food and Agriculture; Unasylva 231/232. An international journal of forestry and forest industries, Volume 60, 5-63.

Pramova E, Locatelli B, Djoudi H, and Somorin OA (2012) Forests and trees for social adaptation to climate variability and change. WIREs Clim Change,3: 581-596.

Quinn CH, Ziervogel G, Taylor A, Takama T, and Thomalla F (2011) Coping with Multiple Stresses in Rural South Africa. Ecology and Society 16(3): 2 , 1-20.

Ribot JC (2003) Democratic decentralisation of natural resources: institutional choice and discretionary power transfer in sub-Sahara Africa. Public Administration and Development, 23:53-65.

Rosmarin J (2013) Vhembe biospehere reserve. Retrieved August 1, 2014, from Environmental Affairs: www.environment.gov.za/?q=content/projects_programmes/manand_thebiosphere_reserves/list/vhemb $\underline{\mathrm{e}}$

Sallu S.M., Twyman C., and Stringer L.C. (2010). Resilient or vulnerable livelihoods? Assessing livelihood dynamics and trajectories in rural Botswana. Ecology and Society 15(4): 3. [online] URL: http://www.ecologyandsociety.org/vol15/iss4/art3/ 
Sen, A. (2004). Elements of a theory of human rights. Phil. Publ. Aff. 32, 315-356

Shackleton CM (2004) Assessment of the livelihoods importance of forestry, forests and forest products in South Africa, Rhodes University, Grahamstown.

Shackleton S, Campbell B, Wollenberg E, and Edmunds D(2002) Devolution and community-based natural resource management: creating space for local people to participate and benefit? ODI Natural Resource perspectives. Number 76, March 2002. ISSN: 1356-9228. www.odi.org.uk/nrp

Shackleton SE, and Campbell BM (2001) Devolution in natural resource management: Institutional arrangements and power shifts. A synthesis of case studies from southern Africa. SADC Wildlife Sector Natural Resource Management Programme, Lilongwe \& WWF (Southern Africa), Harare.

Smith J, Scherr SJ (2002) Clean development mechanism, projects, forests, community involvement, community forestry, policy, socioeconomics, social impact. CIFOR Occasional Paper no. 37. DOI: $10.17528 /$ cifor/001086

Somorin OA (2010) Climate impacts, forest-dependent rural livelihoods and adaptation strategies in Africa: A review. African Journal of Environmental Science and Technology, 4(13), 903-912.

Speranza C. I., Wiesmann U., and Rist, S. (2014). An indicator framework for assessing livelihood resilience in the context of social-ecological dynamics. Glob. Environ. Change 28, 109-119

Tanner T., Lewis D., Wrathall D., Bronen R., Cradock-Henry N., Huq S., Lawless C., Nawrotzki R., Prasad V., Rahman A., Alaniz R., King K., McNamara K., Nadiruzzaman M., Henly-Shepard S., and Thomalla F. (2015). Livelihood resilience in the face of climate change. Nature Climate Change 5, 23-26 doi:10.1038/nclimate2431

Tschakert, P, and K A Dietrich. (2010). Anticipatory Learning for Climate Change Adaptation and Resilience. Ecology and Society 15: 11. G:IPublicationsDownloadlResilienceltschakert.

Tompkins, E. L., and Adger W.N. 2004. "Does Adaptive Management of Natural Resources Enhance Resilience to Climate Change?” Ecology \& Society. http://eprints.soton.ac.uk/202863/

Turpie J, and Visser M (2013) The impact of climate change on South Africa's rural areas. In F. a. Commission, Submission for the 2013/14 Division of Revenue (pp. 100-162). Cape Town: Financial and Fiscal Commission.

Turyahabwe N, Geldenhuys CJ, Watts S, and Banana AY(2006) Technical and institutional capacity in local organisations to manage decentralised forest resources in Uganda, The Southern African Forestry Journal, 208(1),63-78, DOI: 10.2989/10295920609505263

Underwood M (1999) Base-line training needs assessment for community forestry in South Africa. RDFN paper 24d - Winter 1998/99. Rural Development Forestry Network. www.oneworld.org/odi 
United Nations Development Programme: UNDP. 2013. Promoting Sustainable Livelihoods, Reducing Vulnerability and Building Resilience in the Drylands: Lessons from the UNDP Integrated Drylands Development Programme. New York, NY, 10017, USA.

http://www.undp.org/content/dam/undp/library/Environment\%20and\%20Energy/sustainable\%20land\% 20management/Promoting\%20Sustainable\%20Livelihoods, \%20Reducing\%20Vulnerability\%20and\%2 0Building\%20Resilience \%20in\%20the\%20Drylands.\%20Lessons \%20from\%20the\%20UNDP\%20INte grated\%20Drylands\%20Development\%20Programme.pdf [16 October, 2017]

Vedeld P, Angelsen A, Sjaastad E, and Berg GE (2004) Counting on the Environment: Forest Incomes and the Rural Poor. Environmental economics series, Paper no. 98. The World Bank Environment Department.

Von Maltitz G, Mucina L, Geldenhuys C, Lawes M, Eeley H, and Adie H (2003) Classification system for South African indigenous forests. Department of Water Affairs and Forestry (DWAF). Pretoria, South Africa.

Wiersum K (1997) Indigenous exploitation and management of tropical forest resources: an evolutionary continuum in forest-people interactions. Agriculture, Ecosystems and Environment 63, 1-16.

William DS, Angelsen A, Belcher B, Burgers P, Nasi R, Santoso L, and Wunder S (2005) Livelihoods, forests, and conservation in developing countries: An Overview, World Development, 33 (9),1383-1402.

Wongbusarakum S, and Loper C (2011) Indicators to assess community-level social vulnerability to climate change: An addendum to SocMon and SEM-Pasifika regional socioeconomic monitoring guidelines. First draft for public circulation and field testing

Ziervogel G, New M, Archer van Garderen E, Midgley G, Taylor A, Hamann R, Stuart-Hill S, Myers J, and Warburton M (2014) Climate change impacts and adaptation in South Africa. WIREs Clim Change, 5:605-620. doi: 10.1002/wcc.295 